\title{
Removal of Sulfa Antibiotics in Low-Temperature Water Using Scoria
}

\author{
Rui Li ${ }^{1,2}$, Yuling Zhang, ${ }^{1, *}$, Jiali Wang ${ }^{1,2}$, Hong Qian ${ }^{1,2}$ \\ ${ }^{1}$ Key Laboratory of Groundwater Resources and Environment, Ministry of Education, Jilin University, \\ Changchun 130021, China \\ ${ }^{2}$ Institute of Water Resources and Environment, Jilin University, Changchun 130021, China
}

Received: 21 October 2016

Accepted: 29 December 2016

\begin{abstract}
Scoria, a natural silicate mineral, was used for the adsorption removal of antibiotics from water. The kinetics of adsorption were studied during the experiment and the results showed that the adsorption of three antibiotics (sulfathiazole (ST), sulfamethazine (SM2), and sulfamethoxazole (SMX)) by scoria fit the Freundlich isotherm well. Additionally, batch experiment data were fitted using pseudo first-order and pseudo second-order equations, and the calculated capacities for the three antibiotics were $0.7688,0.7242$, and $0.6341 \mathrm{mg} / \mathrm{g}$, respectively. Moreover, the effects of various water chemistry factors on the removal of the three antibiotics were explored, and $\mathrm{Fe}^{2+}$ and $\mathrm{Mg}^{2+}$ were found to promote the adsorption. The alkalinity and hardness of water both had significant effects on absorption of the three antibiotics by scoria. The carbon content of scoria increased significantly, and energy dispersion spectrum analysis showed that it could remove three sulfa antibiotics from low-temperature $\left(10^{\circ} \mathrm{C}\right)$ water effectively. Overall, scoria is an effective natural material for purifying low-temperature water polluted with ST, SM2, and SMX.
\end{abstract}

Keywords: scoria, removal, antibiotics, effects

\section{Introduction}

Organic contaminants can infiltrate aquifers via various channels. In recent years, antibiotics have been widely applied for treatment of disease in humans and to prevent infections and promote growth in livestock [1-2]. Veterinary drugs, especially antibiotics, have recently gained a great deal of attention as emerging contaminants. Indeed, antibiotics have been detected in groundwater, landfill leachate, and surface water worldwide [3-5]. Moreover, sulfamethazine (SM2), sulfamethoxazole (SMX), and tetracycline have been

*e-mail: 1r4636@163.com found in groundwater in Iowa in the United States [6], while 60 types of drugs, including sulfamethoxazole (SMX), were detected in underground well water samples of Baden-Wuerttemberg in Germany [7]. Sulfamethoxazole and sulfamethazine were also detected in groundwater in Wisconsin in the United States. The frequency of detection of SMX and SM2 were 70\% and 10\%, respectively [4]. At least eight kinds of drugs can be simultaneously detected when analyzing any three samples, and the detection rate can reach $20 \%$. Four kinds of sulfa antibiotics have also been detected at sites offshore of Xiamen at levels of 2-9 $\mathrm{ng} / \mathrm{L}$ [8]. The abuse of antibiotics not only harms the environment, but also has the potential to damage human health [9-10]. 
Sulfathiazole (ST), sulfamethazine (SM2), and sulfamethoxazole (SMX) have commonly been used as additives for sulfa antibiotics of which trace levels have been detected [11-17]. Four types of sulfa antibiotics were found in samples of soil and groundwater in a farm in northeastern China [18]. Domestic sewage and aquaculture wastewater containing antibiotics can threaten the safety of residents' drinking water. Despite the threat of trace amounts of antibiotics, there are no drinking water standards for antibiotics in China at present. Nevertheless, identifying methods of removing sulfa antibiotics from water has received a great deal of attention [19-22]. Removal of antibiotics from drinking water [23] using nanofiltration has been investigated; however, experiments showed that the small molecules required nanofilters of smaller aperture [24]. As a result, this process is easily hindered by membrane fouling and decreasing membrane flux, resulting in the need for much more energy. Activated carbon is a common adsorbent for pollutant removal, and experiments have shown that activated carbon powder has good effects on the removal of trace antibiotics [25], with smaller activated carbon particles and longer treatment times producing better results, but at a higher cost.

Scoria is a natural silicate of lightweight aggregate formed during volcanic eruptions. Because of its porosity, low density, and adsorption capacity, scoria has been widely studied for its potential use in building materials such as lightweight concrete [26]. Scoria has also been used as a material for removing fluoride from groundwater by adsorption [27-28]. However, few studies have investigated the removal of contaminants by scoria. In light of its porosity, low weight, uniform particles, and good adsorption performance, scoria has a unique advantage for the removal of contaminants. Therefore, this study investigated the use of scoria for removal of sulfa antibiotics from water to determine its potential for large-scale contaminant removal.

\section{Materials and methods}

\section{Main Materials}

Scoria with a particle size of $0.85-2 \mathrm{~mm}$ (after treatment) was obtained from a volcanic field in northeast Jilin Province, China. Three antibiotics (ST, SM2, and SMX) were purchased from Sigma (St. Louis, MO, USA). All chemical reagents were of analytical grade and purchased from Beijing Chemical Co. (Beijing, China). The solutions of three antibiotics were prepared by diluting antibiotic solutions with deionized water.

\section{Experimental Methods}

To investigate the influence of water chemistry factors on antibiotic adsorption, $0.50 \mathrm{~g}$ of scoria were added into antibiotic solution at $5.00 \mathrm{mg} / \mathrm{L}$ in a $60.00 \mathrm{~mL}$ polyethylene bottle. The water environment in bottles was confirmed with the following requirements (Table 1) and
Table 1. Ion concentrations in each group after mixing (mg/L).

\begin{tabular}{|c|c|c|c|c|c|}
\hline & \multicolumn{5}{|c|}{ Ion Concentration } \\
\hline Group & $\mathrm{Mn}^{2+}$ & $\mathrm{Fe}^{2+}$ & $\mathrm{CO}_{3}^{2-}$ & $\mathrm{Ca}^{2+}$ & $\mathrm{Mg}^{2+}$ \\
\hline $\mathrm{C} 1$ & 0 & 0 & 0 & 0 & 0 \\
\hline $\mathrm{C} 2$ & 0.50 & 0.50 & 5.00 & 50.00 & 50.00 \\
\hline $\mathrm{C} 3$ & 1.00 & 5.00 & 10.00 & 100.00 & 100.00 \\
\hline $\mathrm{C} 4$ & 2.00 & 10.00 & 30.00 & 200.00 & 200.00 \\
\hline $\mathrm{C} 5$ & 4.00 & 30.00 & 50.00 & 300.00 & 300.00 \\
\hline $\mathrm{C} 6$ & 8.00 & 50.00 & 100.00 & 500.00 & 500.00 \\
\hline
\end{tabular}

a control group was set, then the bottles were shaken at $120 \mathrm{rpm}$ in an incubator shaker for 4 hours and kept at $10^{\circ} \mathrm{C}$. The concentration of antibiotics in the supernatant was analyzed by high-performance liquid chromatography (HPLC-UC) using an Agilent Intelligent UV detector (270 $\mathrm{nm})$, the chemical compositions of scoria were analyzed by an energy dispersion x-ray detector (EDX) (JSM6700F on Windows NT, 2010), and the scoria's carbon (C) content was analyzed through the EDX spectrum before and after adsorption.

\section{Batch Equilibrium and Kinetic Adsorption}

A batch experiment was conducted to determine the reaction time required to reach adsorption equilibrium. Briefly, scoria $(0.50 \mathrm{~g})$ was added to a series of 60 polyethylene bottles with $40 \mathrm{~mL}$ diluted solutions (0.5-10 $\mathrm{mg} / \mathrm{L})$, after which the bottles were shaken at $120 \mathrm{rpm}$ and kept at $8^{\circ} \mathrm{C}$ for various lengths of time in an incubator shaker. The quantity of adsorbed antibiotics was then calculated based on the difference between the initial and residual amounts of antibiotics in solution. The antibiotics adsorption at equilibrium was calculated using the following equation:

$$
\mathrm{q}_{\mathrm{e}}=\frac{\left(C_{0}-C_{e}\right) V}{M}
$$

... where $\mathrm{q}_{\mathrm{e}}$ is the equilibrium concentration, $\mathrm{C}_{0}$ and $\mathrm{C}_{\mathrm{e}}$ are the initial concentration and equilibrium concentrations of antibiotics, respectively, $\mathrm{M}$ is the mass of scoria, and $\mathrm{V}$ is the volume of the solution. The initial concentrations were set at $0.5,1,2,5,8$, and $10 \mathrm{mg} / \mathrm{L}$. The samples were filtered through a $0.22 \mu \mathrm{m}$ cellulose membrane and the concentration of antibiotics were analyzed by HPLC-UV. All batch experiments were conducted at $8^{\circ} \mathrm{C}$ and all experiments were repeated three times.

\section{Test Methods}

Water samples were filtered through cellulose membranes $(0.22 \mu \mathrm{m})$ before detection, after which the concentrations of ST, SM2, and SMX were measured by HPLC. Analyses were conducted using an XDB C18 
column (4.6 $\mathrm{mm} \times 150 \mathrm{~mm} \times 5 \mu \mathrm{m})$, a column temperature of $25^{\circ} \mathrm{C}$, and a UV detector wavelength of $270 \mathrm{~nm}$. The mobile phase consisted of methanol and $0.1 \%$ formic acid at a 3:7 ratio. The injection volume was $20 \mu \mathrm{L}$ and the flow rate was $1 \mathrm{~mL} / \mathrm{min}$.

The microstructure physical composition and mineral composition of scoria were analyzed by scanning electron microscopy.

\section{Results and Analysis}

\section{Adsorption Kinetics}

The experimental kinetics data used to examine the mechanism controlling adsorption processes were fitted using pseudo first-order and pseudo second-order equations as follows:

(a) pseudo first-order $\log \left(\mathrm{q}_{\mathrm{e}}-\mathrm{q}_{\mathrm{t}}\right)=\log \mathrm{q}_{\mathrm{e}}-\left(\frac{\mathrm{k}_{1}}{2.303}\right) \mathrm{t}$

(b) pseudo second-order $\frac{\mathrm{t}}{\mathrm{q}_{\mathrm{t}}}=\frac{1}{\mathrm{k}_{2} \mathrm{q}_{\mathrm{e}}^{2}}+\frac{\mathrm{t}}{\mathrm{q}_{\mathrm{e}}}$

...where $\mathrm{q}_{\mathrm{e}}$ and $\mathrm{q}_{\mathrm{t}}$ were the adsorption capacity of antibiotics at equilibrium and at time $\mathrm{t}(\mathrm{min})$, respectively, and $\mathrm{k}_{1}$ and $\mathrm{k}_{2}$ were the rate constant of pseudo first- and second-order adsorption, respectively.

The quasi second-order kinetic model was based on the assumption that the adsorption rate was determined by the square of the unoccupied adsorption vacancies on the adsorbent's surface, and the linear relationship between $\mathrm{t}$ and $\mathrm{t} / \mathrm{q}_{\mathrm{t}}$ indicated that the adsorption had secondary adsorption kinetics characteristics.

Linear plots of pseudo first- kinetics and second-order kinetics are shown in Figs 1 and 2. According to the fitted curves in Fig 2. 1 and 2, the parameters were shown in Table 2. As shown in the table, the adsorption data were well represented by the pseudo second-order model as indicated by regression correlation coefficients of $\mathrm{R}^{2}>0.99$ for the three antibiotics. These findings demonstrated that the experimental results were better described by the quasi second-order kinetic model than the pseudo first-order model, so the rate-limiting step would be the adsorption mechanism. The calculated $\mathrm{q}_{e}$ values of the three antibiotics were $0.7688,0.7242$, and $0.6341 \mathrm{mg} / \mathrm{g}$, respectively.

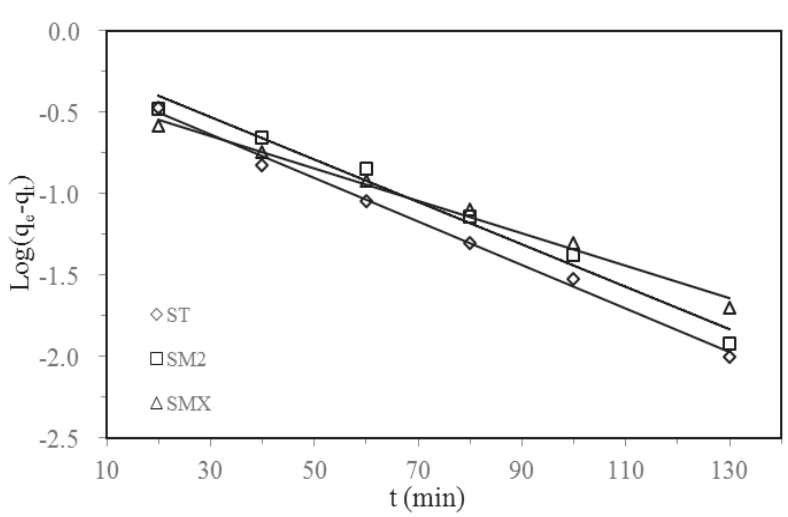

Fig. 1. Linear plot of pseudo-first-order kinetics.

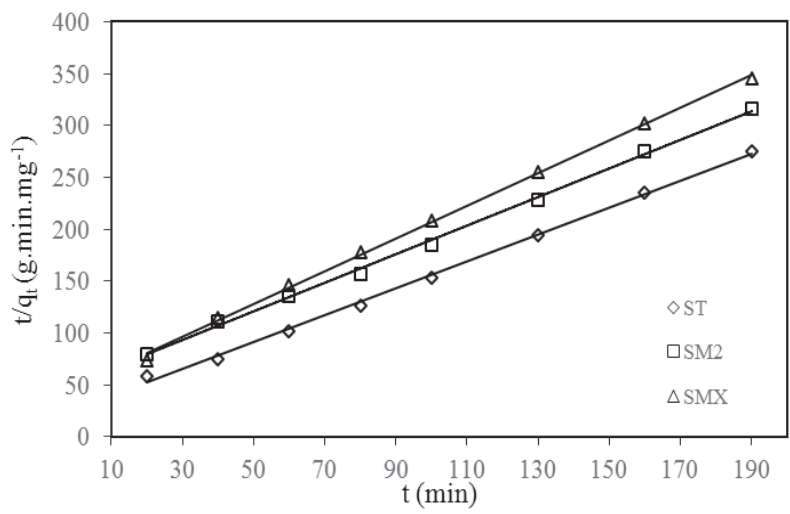

Fig. 2. Linear plot of pseudo-second-order kinetics.

\section{Adsorption Isotherms}

Equilibrium adsorption isotherms such as Langmuir and Freundlich isotherms were not only important methods to reflect the adsorption characteristics, but also the adsorption theory of the practical application system, which was developed according to the assumption that every adsorption was equivalent and the ability of a particle to bind there was independent of whether or not adjacent positions were occupied.

(c) Langmuir equation: $\frac{1}{\mathrm{q}_{\mathrm{e}}}=\frac{1}{\mathrm{q}_{\mathrm{m}}}+\frac{1}{\mathrm{~K}_{\mathrm{L}} \mathrm{q}_{\mathrm{m}}} * \frac{1}{C_{\mathrm{e}}}$

(d)Freundlich equation: $\quad \log \mathrm{q}_{\mathrm{e}}=\log \mathrm{K}_{\mathrm{f}}+\frac{1}{\mathrm{n}} \log \mathrm{C}_{\mathrm{e}}$

Table 2. Kinetic parameters for the removal of three antibiotics by scoria.

\begin{tabular}{|c|c|c|c|c|c|c|}
\hline \multirow{2}{*}{ Adsorbate } & \multicolumn{3}{|c|}{ Pseudo first-order } & \multicolumn{3}{c|}{ Pseudo second-order } \\
\cline { 2 - 7 } & $\mathrm{q}_{\mathrm{e}}(\mathrm{mg} / \mathrm{g})$ & $\mathrm{K}_{1}$ & $\mathrm{R}^{2}$ & $\mathrm{q}_{\mathrm{e}}(\mathrm{mg} / \mathrm{g})$ & $\mathrm{K}_{2}$ & $\mathrm{R}^{2}$ \\
\hline ST & 0.5825 & 0.0309 & 0.995 & 0.7688 & 0.0654 & 0.9981 \\
\hline SM2 & 0.4532 & 0.0299 & 0.982 & 0.7242 & 0.037 & 0.998 \\
\hline SMX & 0.7295 & 0.0230 & 0.9886 & 0.6341 & 0.0506 & 0.9988 \\
\hline
\end{tabular}


...where $\mathrm{q}_{e}$ is the equilibrium concentration, $\mathrm{C}_{\mathrm{e}}$ is the equilibrium concentration, $\mathrm{K}_{\mathrm{L}}$ is the Langmuir equilibrium coefficient, and $\mathrm{K}_{\mathrm{f}}$ and $\mathrm{n}$ are the Freundlich equilibrium coefficients.

Langmuir and Freundlich equations were plotted for the three antibiotics, and the respective parameters are shown in Table 3. The $\mathrm{R}^{2}$ values of all of the regression correlation coefficients were $>0.93$, which suggested that Freundlich models were more suitable for describing the adsorption behavior of three antibiotics. Therefore, the Langmuir equation was not suitable for describing the adsorption behavior of the three antibiotics because this model assumes that the adsorption and desorption rates are identical. Freundlich's equation was more suitable for adsorption by scoria, and the regression correlation coefficients of the three antibiotics were $0.9441,0.9465$, and 0.9378 , respectively.

\section{Influence of Water Chemistry Factors on Antibiotics Adsorption by Scoria}

\section{Influences of Fe and $\mathrm{Mn}$}

Iron and manganese are trace elements essential for human health. Iron is the most abundant transition metal in several tissues and is involved in many processes, including DNA and protein synthesis. Although $\mathrm{Fe}$ deficiency will lead to a variety of motor disorders [2931 ], long-term consumption of water enriched with $\mathrm{Fe}$ or $\mathrm{Mn}$ has adverse effects on health. The main form of $\mathrm{Fe}$ in natural groundwater is $\mathrm{Fe}^{2+}$, which is easily oxidized to $\mathrm{Fe}^{3+}$, resulting in turbid groundwater. In groundwater, Fe and Mn coexisted, with Mn showing valence values from +2 to +7 . These findings are not surprising because these are the most common valence states and all other states except +2 and +4 are very unstable in groundwater under neutral conditions. Manganese is commonly found in the form of suspended particulates or solid matter in groundwater and in the form of $\mathrm{Mn}^{2+}$ and +4 in natural groundwater. The content of iron is generally $5-10 \mathrm{mg} / \mathrm{L}$ and the content of manganese is approximately $0.5-2.0 \mathrm{mg} / \mathrm{L}$ in groundwater throughout most of China. This study explored the effects of $\mathrm{Fe}^{2+}$ and $\mathrm{Mn}^{2+}$ on the adsorption of three antibiotics by scoria (Figs 3 and 4).

Both $\mathrm{Fe}^{2+}$ and $\mathrm{Mn}^{2+}$ played a positive role in the absorbance of the three antibiotics by scoria. Adsorption effects of antibiotics by different ions at different concentrations differed. Overall, the increase in adsor-

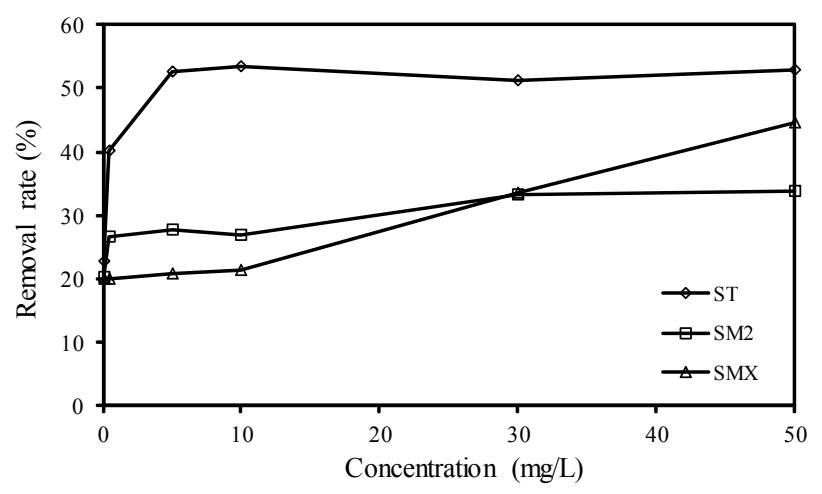

Fig. 3. Effect of $\mathrm{Fe}^{2+}$.

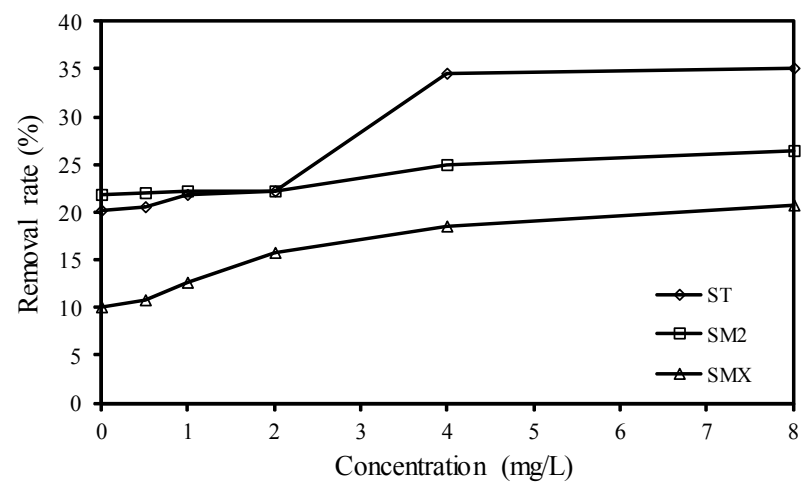

Fig. 4. Effect of $\mathrm{Mn}^{2+}$.

bance capacity of the three antibiotics promoted by $\mathrm{Fe}^{2+}$ was greater than that promoted by $\mathrm{Mn}^{2+}$. Under the condition of high iron and manganese content, $\mathrm{Fe}^{2+}$ can be partially oxidized to $\mathrm{Fe}^{3+}$ during the adsorption process. This leads to hydrolysis and production of $\mathrm{Fe}(\mathrm{OH})_{3}$, which has a high adsorption ability; therefore, removal efficiency increased. However, the removal efficiency of the three antibiotics in the $\mathrm{Mn}^{2+}$ solution was lower than that in the $\mathrm{Fe}^{2+}$ solution. There were different reasons for these results. On one hand, it was not easy for $\mathrm{Mn}^{2+}$ to hydrolyze and produce colloid substances when the concentration of $\mathrm{Mn}^{2+}$ solution was low. On the other hand, the functional groups of antibiotics $\left(-\mathrm{NH}_{2}\right)$ were generated by hydrolysis and the hydrolysis product $\mathrm{OH}^{-}$reacted with $\mathrm{Mn}^{2+}$ to form $\mathrm{Mn}(\mathrm{OH})_{2}$, which caused the amount of $\mathrm{Mn}^{2+}$ to decrease. Overall, the results showed that scoria has a good effect on adsorption removal of ST, SM2, and SMX from groundwater.

Table 3. Langmuir and Freundlich parameters for adsorption of the three antibiotics.

\begin{tabular}{|c|c|c|c|c|c|c|}
\hline \multirow{2}{*}{ Adsorbate } & \multicolumn{3}{|c|}{ Langmuir model } & \multicolumn{3}{c|}{ Freundlich model } \\
\cline { 2 - 7 } & $\mathrm{q}_{\mathrm{m}}(\mathrm{mg} / \mathrm{g})$ & $\mathrm{b}\left(\mathrm{L} \mathrm{mg}^{-1}\right)$ & $\mathrm{R}^{2}$ & $\mathrm{~K}_{\mathrm{f}}$ & $\mathrm{n}$ & $\mathrm{R}^{2}$ \\
\hline $\mathrm{ST}$ & 0.6954 & 5.6840 & 0.7751 & 0.1370 & 2.2889 & 0.9441 \\
\hline SM2 & 0.5312 & 5.5050 & 0.8164 & 0.1173 & 2.2148 & 0.9465 \\
\hline SMX & 0.4445 & 6.3855 & 0.8057 & 0.0969 & 2.2124 & 0.9378 \\
\hline
\end{tabular}




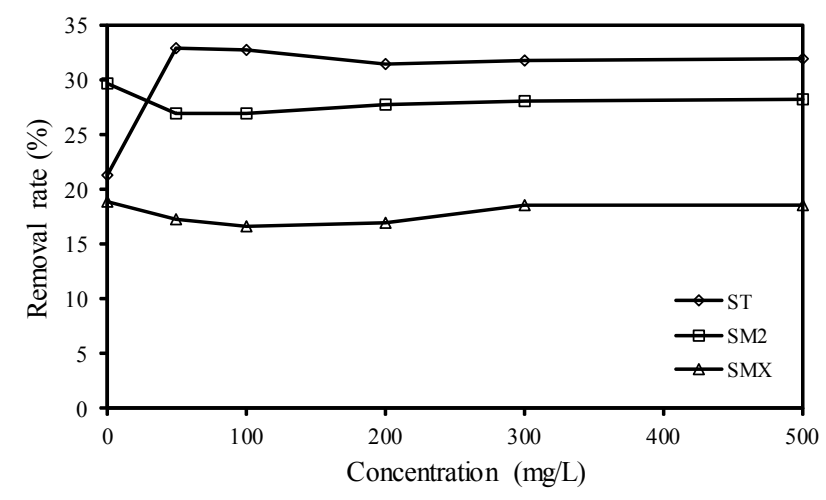

Fig. 5. Effect of $\mathrm{Ca}^{2+}$.

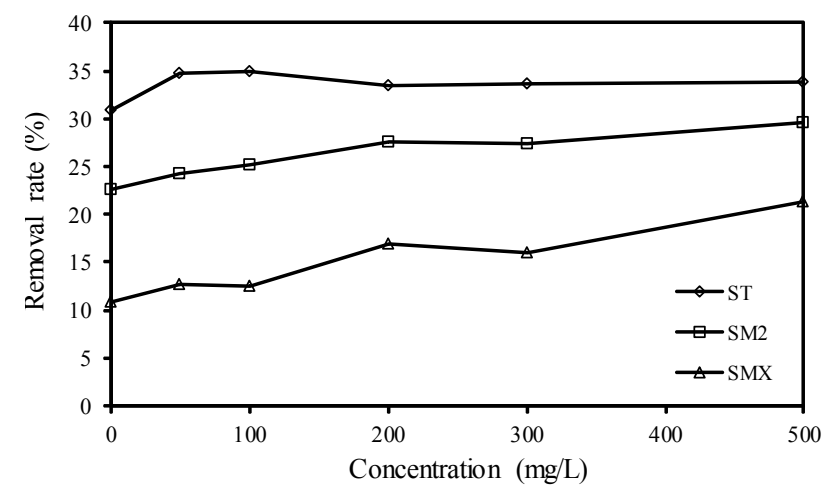

Fig. 6. Effect of $\mathrm{Mg}^{2+}$.

\section{Effect of Hardness}

Hardness of water, which is mainly determined by the content of cations such as calcium and magnesium [32], is an important water quality monitoring index. According to the hygienic standard for drinking water (GB5749-2006), the limit for hardness of drinking water is $450 \mathrm{mg} / \mathrm{L}$ (based on $\mathrm{CaCO}_{3}$ ). Moreover, the hardness of water has significant effects on industries such as leather making [33]. In the present study, the influence of water hardness on the adsorption of three antibiotics by scoria was investigated. All samples showed concentrations of $\mathrm{Ca}^{2+}$ and $\mathrm{Mg}^{2+}$ below $500 \mathrm{mg} / \mathrm{L}$ (Figs 5 and 6).

As shown in Fig. 5, $\mathrm{Ca}^{2+}$ had a negative effect on SM2 and SMX absorbance, but a positive effect on ST absorbance, which improved by $50 \%$. Additionally, $\mathrm{Mg}^{2+}$ promoted the absorption of all three antibiotics, with that of SMX doubling. Overall, both $\mathrm{Mg}^{2+}$ and $\mathrm{Ca}^{2+}$ had positive effects on adsorption of ST. Additionally, the effects of water hardness on adsorption were much weaker than those of $\mathrm{Fe}^{2+}$ and $\mathrm{Mn}^{2+}$, primarily because $\mathrm{Ca}^{2+}$ and $\mathrm{Mg}^{2+}$ were harder to hydrolyze, which led to the formation of lower amounts of hydrolysis products and therefore reduced antibiotics adsorption.

\section{Influences of Alkalinity}

Alkalinity is a measure of the capacity of water to neutralize acids, which is important to drinking and

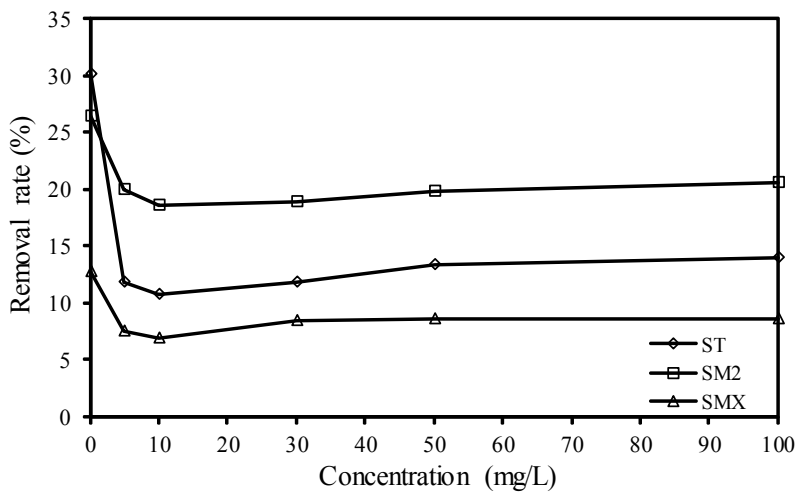

Fig. 7. Effect of alkalinity.

irrigation water. One of the most common ions present in groundwater is $\mathrm{CO}_{3}^{2-}$, which is a major factor of alkalinity in groundwater and plays an important role in the regulation of $\mathrm{pH}$ balance and maintenance of homeostasis in humans. Accordingly, it is necessary to test for $\mathrm{CO}_{3}{ }^{2-}$ in domestic water and drinking water. Because it is easily hydrolyzed under certain conditions, solutions become alkaline when they contain $\mathrm{CO}_{3}{ }^{2-}$. In the present study, we explored the effects of $\mathrm{CO}_{3}{ }^{2-}$ on adsorption of the three antibiotics by scoria (Fig. 5).

As shown in Fig. 5, $\mathrm{CO}_{3}{ }^{2-}$ inhibited the adsorption of the investigated antibiotics by scoria. Specifically, the adsorption of ST, SM2, and SMX decreased by $16 \%$, $6 \%$, and $4 \%$, respectively. The negative effects occurred because amino $\left(-\mathrm{NH}_{2}\right)$ groups reacted with hydrogen ions of water, forming weakly covalently charged ions that led to an overall increase in the concentration of hydroxyl ions, causing the solution to become alkaline. However, the presence of $\mathrm{OH}^{-}$in water inhibited the hydrolysis of amino groups $\left(-\mathrm{NH}_{2}\right)$ because they can react with $\mathrm{H}_{2} \mathrm{O}$ and produce $\mathrm{OH}^{-}$. $\mathrm{CO}_{3}{ }^{2-}$ can continuously hydrolyze with water, causing the solution to become alkaline. This change in alkalinity decreases antibiotics solubility and therefore their removal rates decreased.

\section{Physical and Chemical Indicators and Characterization of Microstructure of Scoria}

Scoria is a low-density and porous material formed by magma passing through volcanic channels and cooling. The pores in scoria form after gas escapes during the cooling process, resulting in its porous, lightweight, particle uniformity, high permeability, and good hydraulic

Table 4. Main compounds of scoria

\begin{tabular}{|c|c|c|c|}
\hline Compounds & Contents & Compounds & Contents \\
\hline $\mathrm{SiO}_{2}$ & $48-50 \%$ & $\mathrm{CaO} \mathrm{MgO}$ & $10-15 \%$ \\
\hline $\mathrm{Al}_{2} \mathrm{O}_{3}$ & $15-20 \%$ & others & $<5 \%$ \\
\hline $\mathrm{Fe}_{2} \mathrm{O}_{3}$ & $10-15 \%$ & & \\
\hline
\end{tabular}


Table 5. Physical and chemical properties of scoria.

\begin{tabular}{|c|c|c|c|}
\hline Indexes & Quantity & Indexes & Quantity \\
\hline Density & $500-600 \mathrm{Kg} / \mathrm{m}^{3}$ & Surface area & $8 \times 10^{3}-1.5 \times 10^{4} \mathrm{~cm}^{2} / \mathrm{g}$ \\
\hline Share & $2.4-2.6$ & Intercepted impurities & $10-13 \mathrm{Kg} / \mathrm{m}^{3}$ \\
\hline Compressive strength & $7.00-8.25 \mathrm{Kg} / \mathrm{cm}^{2}$ & Nonuniformity coefficient & $1.4-1.6$ \\
\hline Porosity & $74-78 \%$ & Head loss & $<12 \mathrm{~cm} / \mathrm{m}$ \\
\hline
\end{tabular}

conductivity. These characteristics impart scoria with unique advantages for dealing with contaminated groundwater. Scoria has been investigated for its potential for use in building materials; however, few investigations of its use in water treatment have been conducted. The main components of scoria are quartz, alkali-feldspar, plagioclase, and clay, and these components are the primary factors influencing its activity. Different components of scoria have different effects on its adsorption capacity. As shown in Tables 4 and 5, the major oxides of scoria are $\mathrm{SiO}_{2}, \mathrm{Al}_{2} \mathrm{O}_{3}, \mathrm{Fe}_{2} \mathrm{O}_{3}, \mathrm{CaO}$, and $\mathrm{MgO}$.

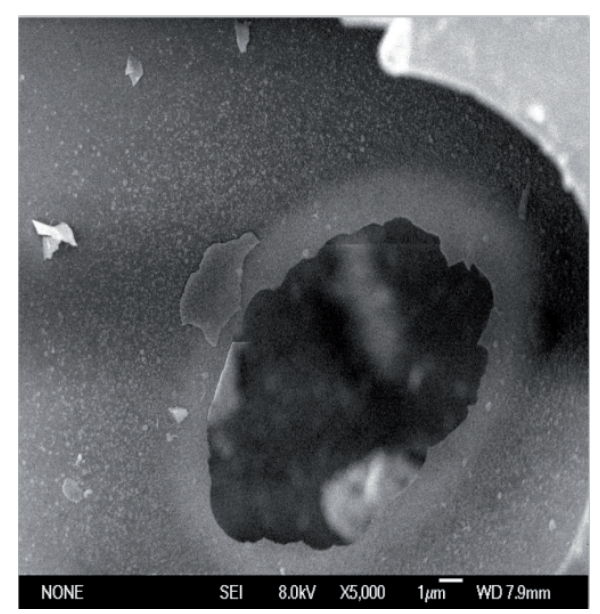

Fig. 8. SEM micrograph before adsorption.

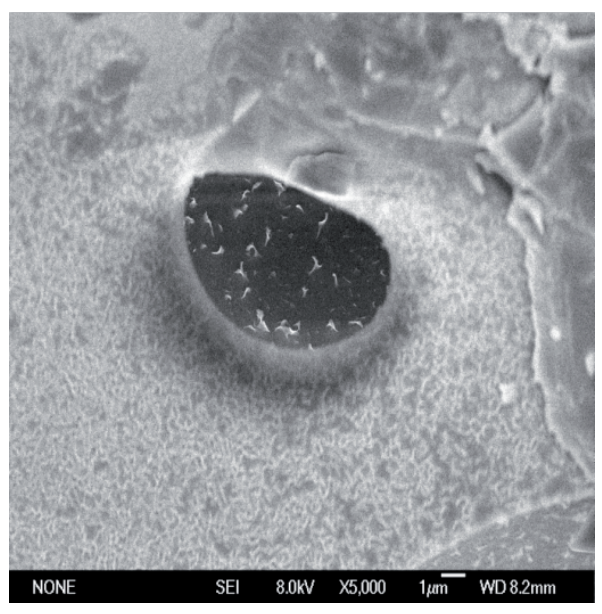

Fig. 9. SEM micrograph after adsorption.

\section{Analysis of Microstructure and Energy Dispersion Spectrum of Scoria}

The structure and morphology of materials were observed by scanning electron microscopy. The results revealed uneven surfaces and abundant pore structures, with pore diameters ranging from 5 to $14 \mu \mathrm{m}$. Moreover, the materials were found to contain a large number of well-developed microscopic pore structures that provided the optimum conditions for scoria to adsorb antibiotics. As shown in the SEM micrographs, the surface of scoria was relatively smooth before adsorption compared with that after adsorption, and there were few granular substances on the surface before adsorption. Moreover, some antibiotics collected on the surface and in the surface pores of scoria after adsorption, resulting in the surface becoming rough (Fig. 10).

The components and characteristics of scoria are major factors influencing its absorption effects. The main compounds of scoria were found to be $\mathrm{SiO}_{2}, \mathrm{Al}_{2} \mathrm{O}_{3}$, $\mathrm{Fe}_{2} \mathrm{O}_{3}, \mathrm{CaO}$, and $\mathrm{MgO}$ (Table 4). Silicate, which has a tetrahedral structure, was the primary mineral component. It promoted chemical adsorption [33]. The antibiotic was organic, and it is well known that organic compounds interact effectively with scoria on the micro level.

As shown in Figs 11-14, the carbon content of scoria was obviously higher after absorption than the original. Moreover, the peak height of C (carbon) showed greater variation than that of the other elements. This occurred because the test compounds were sulfa antibiotics (Table 6), which mainly consist of carbon and hydrogen.

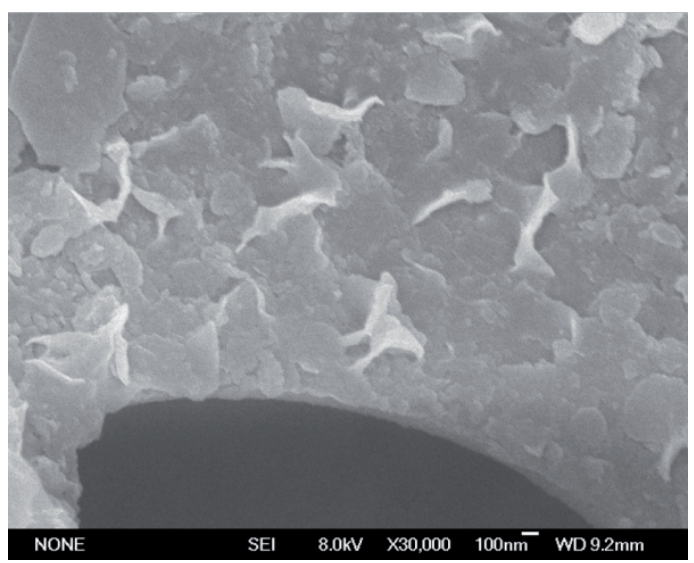

Fig. 10. SEM micrograph after adsorption. 


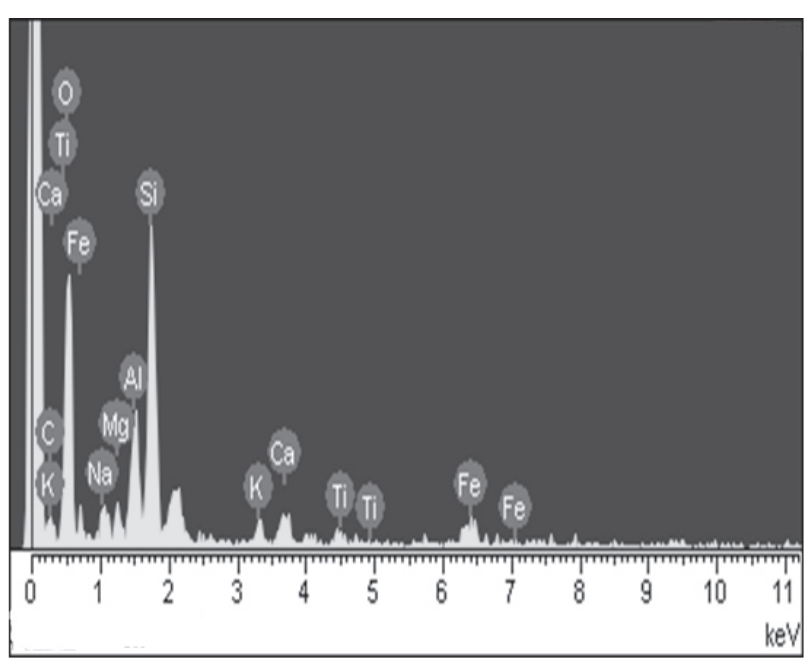

Fig. 11. EDX spectrum of scoria before adsorption.

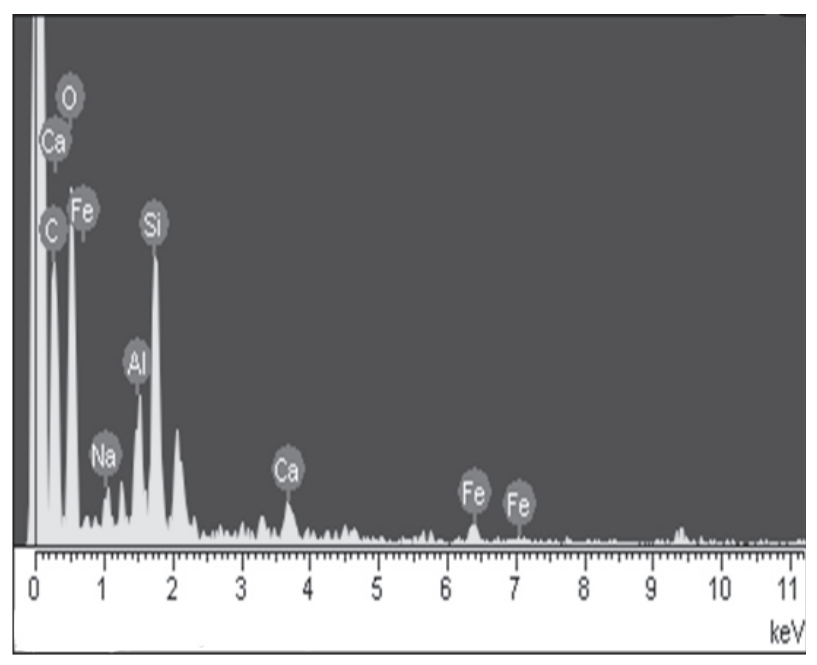

Fig. 12. EDX spectrum of scoria after adsorption of ST.

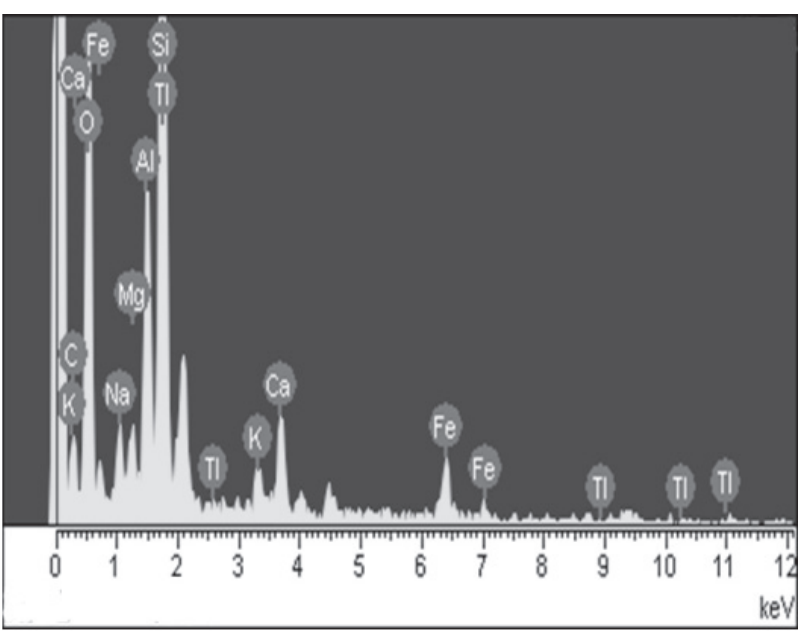

Fig. 13. EDX spectrum of scoria after adsorption of SM2.

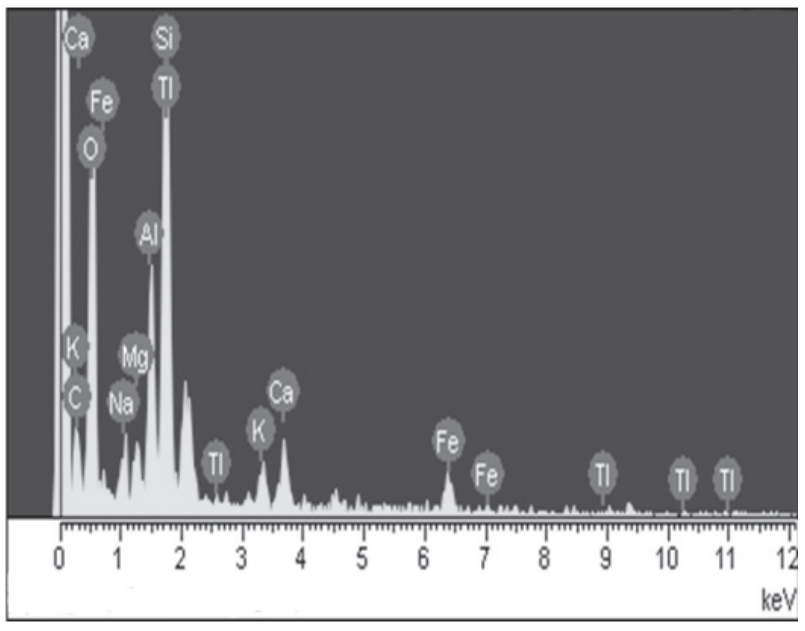

Fig. 14. EDX spectrum of scoria after adsorption of SMX.

Table 6. Basic properties and characteristics of three sulfa antibiotics [35].

\begin{tabular}{|c|c|c|c|}
\hline Antibiotics & Sulfathiazole (ST) & Sulfamethazine (SM2) & Sulfamethoxazole (SMX) \\
\hline Structural formula & 255.3 & 278.3 & 253.3 \\
\hline Molecular formula & 1.70 & 1.39 & 1.08 \\
\hline Molecular weight $\left(\mathrm{g} \mathrm{mol}^{-1}\right)$ & 1.56 & 0.49 & 1.73 \\
\hline Density $\left(\mathrm{g} \mathrm{cm}^{-3}\right)$ & $\mathrm{C}_{9} \mathrm{H}_{9} \mathrm{O}_{2} \mathrm{~N}_{3} \mathrm{~S}_{2}$ & $\mathrm{C}_{10} \mathrm{H}_{11} \mathrm{~N}_{3} \mathrm{O}_{3} \mathrm{~S}^{2}$ \\
\hline Solubility $\left(\mathrm{g} \mathrm{L}^{-1}\right)$ & $25 \mathrm{H}_{14} \mathrm{~N}_{4} \mathrm{O}_{2} \mathrm{~S}$ & 2 \\
\hline
\end{tabular}


As a result, the carbon content of scoria increased after absorption, which agreed with the change of carbon content in the EDX spectrum of scoria after adsorption. Overall, the increasing carbon content indicates that the adsorption of the three antibiotics by scoria was effective.

\section{Conclusions}

1. The results showed that scoria adsorbed the three investigated antibiotics, and that the content of $\mathrm{Fe}^{2+}$ and $\mathrm{Mn}^{2+}$ water hardness and alkalinity in water influenced the adsorption of these compounds. Uneven surfaces and the abundant pore structures of scoria were well developed, which provided good conditions for the adsorption of antibiotics. Overall, scoria was a suitable material for the purification of water containing ST, SM2, and SMX.

2. Ions affected the adsorption of ST, SM2, and SMX by scoria in low-temperature water. However, the effects of ions on their adsorption differed, with $\mathrm{Fe}^{2+}$ and $\mathrm{Mg}^{2+}$ promoting the adsorption of the three kinds of antibiotics by scoria, while $\mathrm{Ca}^{2+}$ promoted their adsorption under some, but not all conditions. Conversely, $\mathrm{Fe}^{2+}, \mathrm{Mn}^{2+}$, and $\mathrm{CO}_{3}{ }^{2-}$ led to decreases in the adsorption of ST, SM2, and SMX of 16, 6, and 4\%, respectively.

3. Kinetic data describing the adsorption were best described by the pseudo second-order model, while the equilibrium experiment data were described by the Freundlich model. Additionally, the rate-limiting step of the process was found to be the adsorption mechanism. The main mineral components of scoria were quartz, alkali feldspar, and plagioclase. Comprehensive research and the EDX spectra of scoria indicated that micro collisions occurred between these materials and antibiotics during the experiment, resulting in their removal from water.

\section{Acknowledgements}

We acknowledge financial support from the major science and technology project of rural drinking water safety (No. 2012BAJ25B10).

\section{References}

1. SINGER R.S, FINCH R., WEGENER H.C, BYWATER R., WALTERS J., LIPSITCH M. Antibiotic resistance the interplay between antibiotic use in animals and human beings. The Lancet Infect. Dis. 3 (1), 47, 2003.

2. CABELLO F.C, Heavy use of prophylactic antibiotics in aquaculture: a growing problem for human and animal health and for the environment. Environ. Microbiol. 8 (7), 1137, 2006.

3. KOLPIN D.W, FURLONG E.T, MEYER M.T, THURMAN E.M, ZAUGG S.D, BARBER L.B, BUXTON H.T.
Pharmaceuticals, Hormones, and Other Organic Wastewater Contaminants in U.S. Streams, 1999-2000: A national reconnaissance. Environ. Sci. Technol. 36 (6) 1202, 2002.

4. KARTHIKEYAN K.G., MEYER M.T. Occurrence of antibiotics in wastewater treatment facilities in Wisconsin, USA, Sci. Total. Environ. 361 (1-3), 196, 2006.

5. ZHANG D., LIN L., LUO Z. Occurrence of selected antibiotics in Jiulongjiang River in various seasons, South China. Environ. Monit. 13 (7), 1953, 2011.

6. SARMAH A.K., MEYER M.T., BOXALL A. A global perspective on the use, sales, exposure pathways, occurrence, fate and effects of veterinary antibiotics (VAs) in the environment .Chemosphere. 65 (5), 725, 2006.

7. SACHER F., LANG F., BRAUCH H., BLANKENHORN I. Pharmaceuticals in groundwater: analytical methods and results of a monitoring Program in Baden-Württemberg, Germany. Journal of Chromatography A. 938 (1-2), 199, 2001.

8. SU Z. Study on Determination Method for 24 Antibiotics in Aquatic Environment Samples and Its Application. Xiamen, Xiamen University. 2008 [In China].

9. BELlANTE D.M.G., BELLANTE L., CHIAVOLA A., APRILE L.D., SBAFFONI S. Pharmaceuticals in the environment .Regulatory Toxicology Pharmacology. 28 (3), 212,1998

10. WEBB S.F. A data-based perspective on the environmental risk assessment of human pharmaceuticals II: Indirect human exposure, in: K. Kummerer (Ed.), Pharmaceuticals in the Environment, Springer-Verlag, Berlin, 221, 1999 [In Germany].

11. MICHELE E., LINDSEY, MEYER M., THURMAN E. Analysis of trace levels of sulfonamide and tetracycline antibiotics in groundwater and surface water using solid-Phase extraction and liquid chromatography/mass spectrometry. Analytical Chemistry. 73 (19), 4640, 2001 [In U.S] .

12. GOKOGLU E., YILMAZ E. Fluorescence Interaction and Determination of Sulfathiazole with Trypsin. Journal of Fluorescence. 24 (5), 1439, 2014.

13. MARTINELLO M., BAGGIO A., GALLINA A., MUTINELLI F. Distribution of Sulfathiazole in Honey, Beeswax, and Honeybees and the Persistence of Residues in Treated Hives. J. Agric. Food Chem. 61 (38), 9275, 2013.

14. GAO Y., GAO N., DENG Y., GU J., ZHANG D. Factor affecting sonolytic degradation of sulfamethazine in water. Ultrasonics Sonochemistry. 20 (6), 1401, 2013.

15. PENG F., YING G., LIU Y., SU H., HE L. Joint antibacterial activity of soil-adsorbed antibiotics trimethoprim and sulfamethazine. Science of The Total Environment. 506 (15), $58,2015$.

16. SU T., DENG H., JONATHAN P., MICHAEL R. Biodegradation of sulfamethoxazole photo-transformation products in a water/sediment test. Chemosphere. 148, 518, 2016.

17. GYURI S., KRISZTINA K., ANIKO B., TAMAS C., ERZSEBET T., LASZLO W. Enhancing the biological degradability of sulfamethoxazole by ionizing radiation treatment in aqueous solution. Radiation Physics and Chemistry. 124 (6), 179, 2016.

18. AI-XIA Z., XIAO-SI S., SONG G., YU-LING Z., XUEYU L., LAN-YING Z., YONG-LEI. Determination of Four Sulfa Antibiotics in Groundwater, Soil and Excreta Samples Using High Performance Liquid Chromatography. Chinese J. Anal Chem. 42 (3), 397, 2014.

19. GöBEL A., THOMSEN A., MCARDELL C.S., JOSS A., GIGER W., Occurrence and Sorption Behavior of 
Sulfonamides, Macrolides, and Trimethoprim in Activated Sludge. Treatment. Environmental Science \& Technology. 39 (11), 3981, 2005.

20. YU F., LI Y., HAN S., MA J.. Adsorptive removal of antibiotics from aqueous solution using carbon materials. Chemosphere. 153(6), 365, 2016

21. CHOI Y., KIM L., ZOH K. Removal characteristics and mechanism of antibiotics using constructed wetlands. Ecological Engineering. 91 (6), 85, 2016.

22. AHMED M., ZHOU J., NGO H., GUO W. Adsorptive removal of antibiotics from water and wastewater: Progress and challenges. Science of The Total Environment. 532 (11), $112,2015$.

23. ROOKLIDGE S.J., MINER J.R., KASSIM T.A., NELSON, P.O. Antimicrobial contaminant removal by multistage slow sand filtration. American Water Works Association. 97 (12), 92, 2005.

24. KOSUTIC K., DOLAR D., ASPERGER D., KUNST B. Removal of antibiotics from a model wastewater by RO/NF membranes. Separation and Purification Technology. 53 (3), 244, 2007.

25. Snyder S.A., WESTERHOFF P., YOON Y., SEDLAK D. L. Pharmaceuticals, personal care products, and endocrine disruptors in water: implications for the water industry. Environ Eng Sci. 20 (5), 449, 2003.

26. SHANNAG M.J., CHARIF A., DGHAITHER S. Developing Structural Lightweight Concrete Using Volcanic Scoria Available in Saudi Arabia. Arab J Sci Eng. 39 (5), 3525, 2014.
27. ZHANG S., LU Y., LIN X., SU X., ZHANG Y. Removal of fluoride from groundwater by adsorption onto $\mathrm{La}(\mathrm{III})$ Al(III) loaded scoria adsorbent. Applied Surface Science. 303 (1), 1, 2014.

28. ZHANG Y., DONG T., SU X.,QIAN H., WANG J. Effect of high fluoride groundwater purification by lightweight aggregate scoria. Environmental Earth Sciences.75 (1), 1, 2016.

29. PERALTA V., CUESTA M.J., MATA I., SERRANO J.F., PEREZ N F., NATIVIDAD M.C. Serum iron in catatonic and non-catatonic psychotic patients. Biol Psychiatry. 45 (6), $788,1999$.

30. ROSEBUSH P.I., MAZUREK M.F. Serum iron and neuroleptic malignant syndrome. Lancet. 338 (8760), 149, 1991.

31. BROWN K., GLEN S., WHITE T. Low serum iron status and akathisia. Lancet. 1 (8544) 1234, 1987.

32. ENTEZARI M.H., TAHMASBI M. Water softening by combination of ultrasound and ion exchange. Ultrasonics Sonochemistry. 16 (3), 356, 2009.

33. BASF Pocket Book for the Leather Technologist, third ed, Germany, 57, 1995.

34. ZHANG S., ZHANG Y., SU X., ZHANG Y. Purification of Petroleum Contaminated Groundwater by Permeable Reactive Barrier Using Scoria as Media. Journal of Jilin University. 42, 393, 2012.

35. ZHOU A. Research on the Migration and Transformation Mechanism and remediation technique of sulfa antibiotics in phreatic water. Changchun, Jilin University. 2014 [In China]. 